\title{
Kesejahteraan Psikologis pada Remaja Panti Asuhan Ditinjau dari Internal Locus of Control dan Spiritualitas
}

\section{Psychological Well-Being of Orphan Adolescents in Terms of Internal Locus of Control and Spirituality}

\author{
Dyah Kantung Sekar Harjanti \\ Fakultas Psikologi, Universitas Sebelas Maret
}

Submitted 14 December 2020 Accepted 1 April 2021 Published 28 May 2021

\begin{abstract}
Parental presence has a big role in a child's psychological well-being, especially during adolescence. However, in reality there are some adolescents who do not get the guidance and affection from their parents, namely adolescents in orphanages. Psychological well-being can be influenced by several factors, such as personality and psychosocial. Personality factor includes internal locus of control, while psychosocial factor includes spirituality. This study aimed to determine the relationship between internal locus of control and spirituality with psychological well-being in adolescents living in orphanages. Population study sampling determined 75 adolescent samples. Sampling used population study technique. Data collection used a psychological well-being scale (28 items, $\alpha=0.881$ ), an internal locus of control scale (22 items, $\alpha=0.856$ ), and a spirituality scale (26 items, $\alpha=0.905)$. Multiple regression results indicated that there was a relationship between internal locus of control and spirituality with psychological well-being $\left(R_{y x} 1 \times 2=0.790 ; p<0.05\right.$. The first simple regression analysis showed there was a positive relationship between internal locus of control and psychological well-being $\left(r_{x} 1_{y}=0.466 ; p<0.05\right)$. The second simple regression analysis showed there was a positive relationship between spirituality and psychological wellbeing $\left(\mathrm{r}_{\mathrm{x}} \mathrm{y}=0.490 ; p<0.05\right)$. This means that the higher the internal locus of control and spirituality a person has, the higher the psychological well-being, and vice versa. The effective contribution of spirituality was greater for psychological well-being by contributing $32.5 \%$, compared to internal locus of control, which was $30 \%$.
\end{abstract}

Keywords: internal locus of control; psychological well-being; spirituality

Abstrak. Kehadiran orang tua berperan besar bagi kesejahteraan psikologis anak, khususnya remaja. Namun realitanya ada sebagian remaja yang tidak mendapatkan bimbingan dan afeksi orang tuanya, yaitu remaja di panti asuhan. Kesejahteraan psikologis dipengaruhi beberapa faktor, seperti kepribadian dan psikososial. Faktor kepribadian misalnya adalah internal locus of control, sedangkan faktor psikososial adalah spiritualitas. Penelitian ini bertujuan untuk mengetahui hubungan antara internal locus of control dan spiritualitas dengan kesejahteraan psikologis pada remaja yang tinggal di panti asuhan. Pengambilan sampel menggunakan teknik studi populasi dengan jumlah 75 remaja. Pengumpulan data menggunakan skala kesejahteraan psikologis (28 butir, $\alpha=0,881$ ), skala internal locus of control (22 butir, $\alpha=0,856$ ), dan skala spiritualitas (26 butir, $\alpha=0,905$ ). Hasil regresi berganda menunjukkan bahwa terdapat hubungan antara internal locus of control dan spiritualitas dengan kesejahteraan psikologis $\left(\mathrm{R}_{\mathrm{yx}} 1 \times 2=0,790 ; p<0,05\right.$. Analisis regresi sederhana pertama menunjukkan terdapat hubungan antara internal locus of control dengan kesejahteraan psikologis $\left(\mathrm{r}_{\mathrm{x}} 1_{\mathrm{y}}=0,466 ; \mathrm{p}<0,05\right)$. Analisis regresi sederhana kedua menunjukkan terdapat hubungan antara spiritualitas dengan kesejahteraan psikologis $\left(\mathrm{r}_{\mathrm{x}} 2_{\mathrm{y}}=0,490 ; p<0,05\right)$. Artinya semakin tinggi internal locus of control dan spiritualitas yang dimiliki seseorang, maka semakin tinggi kesejahteraan psikologisnya, begitu pula sebaliknya. Besar sumbangan efektif spiritualitas lebih besar terhadap kesejahteraan psikologis dengan memberikan sumbangan sebesar 32,5\%, dibandingkan internal locus of control yaitu sebesar $30 \%$.

Kata kunci: internal locus of control; kesejahteraan psikologis; spiritualitas 
Kesejahteraan psikologis remaja di Indonesia menurut Prabowo (2016) belum tercapai dengan optimal karena masih tingginya tingkat kenakalan atau kekerasan pada remaja. Komisi Perlindungan Anak Indonesia (KPAI, 2020) mengungkapkan bahwa pada tahun 2011 hingga 2019, terdapat 37.381 pengaduan kekerasan terhadap anak. Bahkan pada kasus perundungan, angkanya mencapai 2.473 baik di sekolah maupun di media sosial. Hailehiorgis et al. (2018) menemukan bahwa kesejahteraan psikologis remaja yang tinggal di panti asuhan lebih rendah daripada yang tinggal bersama keluarganya. Hal ini diperkuat dengan penelitian Aesijah et al. (2016) yang menunjukkan bahwa remaja di panti asuhan hanya dipandang sebagai makhluk biologis sehingga kebutuhan psikologisnya tidak terpenuhi. Ditemukan bahwa secara emosional, penghuni panti mengalami kondisi kurang sejahtera. Emosi negatif seperti sedih 100\% dirasakan oleh remaja, marah 57,89\%, jengkel $84,21 \%$, susah belajar sebanyak $5,26 \%$, dan kurang percaya diri $21,05 \%$.

Ada tiga fenomena menonjol yang peneliti temukan berdasarkan observasi dan wawancara terhadap lima pengelola panti asuhan yang berlokasi di Karanganyar. Pertama, ditemukan bahwa kondisi kelima panti asuhan mengalami ketidakseimbangan antara jumlah anak asuh dengan jumlah pengasuh sehingga mengakibatkan remaja kurang memperoleh bimbingan dan afeksi secara mendalam. Fenomena selanjutnya, yaitu tiga dari lima pengelola panti asuhan mengungkapkan bahwa remaja memiliki perilaku bermasalah dengan teman sebaya maupun guru di sekolah. Hal ini dapat terlihat dari sebagian remaja yang sering terlibat dalam pertengkaran dan mencoba melarikan diri dari panti asuhan. Fenomena terakhir, yaitu kondisi fisik dan sosial kelima panti asuhan yang dihuni banyak anak asuh menimbulkan kurangnya privasi dan tidak aman.

Fenomena yang peneliti temukan menimbulkan beberapa permasalahan yang berkaitan dengan kesejahteraan psikologis. Fenomena pertama, terkait ketidakseimbangan jumlah anak asuh dengan pengasuh menurut Illahi \& Akmal (2018) mengakibatkan adanya keterbatasan dukungan emosional. Yendork \& Sombhlaba (2014) mengemukakan bahwa tidak terpenuhinya dukungan emosional individu berisiko menurunkan kesejahteraan psikologis. Fenomena kedua, menurut Okti (2019) disebabkan karena remaja tidak mampu membentuk hubungan positif dan kurangnya penerimaan diri yang dimiliki. Hal tersebut mengindikasikan bahwa remaja memiliki kesejahteraan psikologis yang rendah. Fenomena terakhir, bisingnya kondisi fisik dan sosial di panti asuhan menurut Solari \& Mare (2012) berdampak negatif bagi kesejahteraan psikologis remaja tersebut.

Kesejahteraan psikologis pada remaja yang tinggal di panti asuhan penting untuk diteliti. Prabowo (2016) mengemukakan bahwa kesejahteraan psikologis dapat menjadi kekuatan bagi remaja dalam melewati masa kritis dan penuh tantangan pada periode remaja. Ryff (2014) mengemukakan bahwa remaja yang kurang mendapat dukungan orang tua dikaitkan dengan peningkatan gejala depresi dan kondisi kronis di masa dewasa. Oleh karena itu, Ryff (2014) menyarankan bahwa penekanan pada kesejahteraan psikologis remaja akibat pasca trauma perlu dilakukan dalam mengurangi risiko depresi tersebut.

Kesejahteraan psikologis didefinisikan oleh Huppert (2009) sebagai kehidupan yang berlangsung secara baik, yaitu kombinasi dari perasaan baik dan mampu melakukan 
fungsinya secara optimal. Salah satu elemen yang berpengaruh terhadap kesejahteraan psikologis yaitu locus of control. Locus of control menurut Rotter (1966) mengacu pada apakah individu percaya bahwa hasil peristiwa ditentukan oleh tindakannya sendiri atau kebetulan. Individu yang percaya suatu hasil diputuskan oleh tindakannya sendiri digambarkan sebagai individu yang tinggi di internal locus of control. Sebaliknya, individu yang percaya suatu hasil sebagai kebetulan dianggap tinggi di external locus of control. Beberapa penelitian menunjukkan hasil internal locus of control memengaruhi kesejahteraan psikologis. Penelitian Mobarakeh et al. (2015) membuktikan bahwa terdapat hubungan yang signifikan antara internal locus of control dan kesejahteraan psikologis. Locus of control memainkan peran dasar untuk menentukan tingkat penyesuaian dan kesejahteraan psikologis. Individu dengan internal locus of control mampu mengadopsi penguasaan diri dan cenderung memiliki hubungan sosial yang bermanfaat dan berdampak positif pada kinerja kelompoknya sehingga kesejahteraan psikologisnya mengalami peningkatan. Penelitian lain oleh Listiara dan Sari (2017) juga menunjukkan hal serupa. Semakin tinggi internal locus of control, maka semakin tinggi juga kesejahteraan psikologisnya. Moshki dan Ashtarian (2010) menjelaskan bahwa individu dengan internal locus of control memiliki kinerja yang baik secara akademis dan kepercayaan diri yang tinggi pada dirinya sendiri, berbeda dengan individu yang dominan external locus of control sehingga berdampak pada kesejahteraan psikologisnya.

Selain internal locus of control, elemen lain yang dapat memengaruhi kesejahteraan psikologis remaja yaitu spiritualitas. Spiritualitas digambarkan Underwood \& Teresi (2002) sebagai pendekatan individual dan terbuka dalam pencarian makna dan tujuan hidup, sebagai pencarian kebenaran transedental yang mencakup rasa keterkaitan dengan orang lain, alam, dan/atau yang illahi. Beberapa penelitian membuktikan bahwa spiritualitas dapat menjadi faktor yang berpengaruh terhadap kesejahteraan psikologis remaja. Pandya (2017) dalam penelitiannya menunjukkan bahwa remaja yang diberikan program spiritualitas memiliki kesejahteraan psikologis yang lebih tinggi daripada remaja yang tidak diberikan progtam spiritualitas. Penelitian lain yang dilakukan Munthe et al. (2017) menunjukkan bahwa spiritualitas memiliki korelasi positif yang signifikan dengan kesejahteraan psikologis. Lebih lanjut, penelitian Malik dan Tanzeel (2018) mengungkapkan bahwa spiritualitas tidak hanya memiliki korelasi yang positif dengan kesejahteraan psikologis, tetapi juga sebagai prediktor positif yang siginifikan.

Berdasarkan uraian fenomena permasalahan kesejahteraan psikologis di panti asuhan dan pentingnya memiliki internal locus of control dan spiritualitas pada remaja, penelitian ini bertujuan untuk mengetahui hubungan antara internal locus of control dan spiritualitas dengan kesejahteraan psikologis pada remaja yang tinggal di panti asuhan. Adapun penelitian mengenai kesejahteraan psikologis ditinjau dari internal locus of control dan spiritualitas belum pernah dilakukan secara simultan sebelumnya. Lebih lanjut, penelitian mengenai ketiga variabel tersebut belum pernah dilakukan terhadap remaja yang tinggal di panti asuhan. 


\section{Metode}

Penelitian ini menggunakan metode kuantitatif. Populasi yang digunakan pada penelitian ini adalah remaja yang tinggal di Panti Asuhan Seribu Pulau Karanganyar, Panti Hosana Kemenangan Karanganyar, Panti Asuhan SILO Karanganyar, Panti Asuhan Putra Muhammadiyah Karanganyar, dan Panti Asuhan Aisyiyah Karanganyar. Teknik sampling yang digunakan dalam penelitian ini yaitu teknik studi populasi, dan didapatkan jumlah 75 remaja dengan karakteristik: a. Berusia 12-23 tahun; b. Tinggal di panti asuhan minimal selama 1 tahun; c. Bersedia mengisi skala yang ditunjukkan dengan informed consent. Pengumpulan data dilakukan dengan menggunakan tiga skala yang disusun sendiri oleh peneliti dan telah diuji cobakan terhadap panti asuhan yang berlokasi di Trenggalek. Skala yang digunakan yaitu diantaranya skala kesejahteraan psikologis, skala internal locus of control, dan skala spiritualitas. Metode analisis data yang digunakan yaitu regresi linear berganda untuk mengetahui hubungan antara internal locus of control dan spiritualitas dengan kesejahteraan psikologis.

\section{Kesejahteraan psikologis}

Variabel kesejahteraan psikologis dalam penelitian ini diukur menggunakan skala yang disusun sendiri oleh peneliti berdasarkan dimensi kesejahteraan psikologis menurut Ryff (2014), yaitu penguasaan lingkungan, relasi positif, otonomi, pengembangan diri, penerimaan diri, dan tujuan hidup. Skala ini terdiri dari 28 butir dengan 14 butir favorable dan 14 butir unfavourable. Penilaian dilakukan menggunakan skala Likert dengan empat alternatif jawaban yaitu 1 sangat tidak setuju, 2 tidak setuju, 3 setuju, hingga 4 sangat setuju. Uji validitas alat ukur menggunakan professional judgement dan teknik corrected-item-totalcorrelation dengan bantuan program SPSS versi 25.0. Sedangkan uji reliabilitas dilakukan dengan formulasi Cronbach's Alpha ditemukan nilai sebesar $(\alpha)=0,881$.

\section{Internal locus of control}

Variabel internal locus of control dalam penelitian ini diukur menggunakan skala yang disusun sendiri oleh peneliti berdasarkan dimensi locus of control menurut Levenson (1973) yaitu internal, powerful others, dan chance. Skala ini terdiri dari 22 butir dengan 10 butir favorable dan 12 butir unfavorable. Dimensi powerful others dan chance menjadi butir unfavorable karena untuk mengukur tingkat internal locus of control. Penilaian skala ini menggunakan skala Likert dengan empat alternatif jawaban yaitu 1 sangat tidak setuju, 2 tidak setuju, 3 setuju, hingga 4 sangat setuju. Uji validitas alat ukur menggunakan professional judgement yaitu dan teknik corrected-item-total-correlation dengan bantuan program SPSS versi 25.0. Sedangkan uji reliabilitas dilakukan dengan formulasi Cronbach's Alpha ditemukan nilai sebesar $(\alpha)=0,881$.

\section{Spiritualitas}


Variabel spiritualitas dalam penelitian ini diukur menggunakan skala yang disusun sendiri oleh peneliti berdasarkan aspek spiritualitas oleh Elkins, Hedstrom, Hughes, Leaf dan Saunders (1988) yaitu transenden, tujuan dan makna hidup, misi hidup, nilai material, altruisme, idealisme, kesakralan hdup, sadar akan penderitaan, dan buah dari spiritualitas. Skala ini terdiri dari 26 butir dengan 16 butir favorable dan 10 butir unfavorable. Penilaian skala ini menggunakan skala Likert dengan empat alternatif jawaban yaitu 1 sangat tidak setuju, 2 tidak setuju, 3 setuju, dan 4 sangat setuju. Uji validitas alat ukur menggunakan professional judgement dan teknik corrected-item-total-correlation dengan bantuan program SPSS versi 25.0. Sedangkan uju reliabilitas dilakukan dengan formulasi Cronbach's Alpha ditemukan nilai sebesar $(\alpha)=0,905$.

\section{Hasil}

Tabel 1.

Uji Asumsi Dasar Normalitas Data Penelitian

\begin{tabular}{cccc}
\hline Variabel & Signifikansi & $p$ & Bentuk \\
\hline $\begin{array}{c}\text { Internal Locus of Control, Spiritualitas, } \\
\text { dan Kesejahteraan Psikologis }\end{array}$ & 0,200 & $p>0,05$ & Normal \\
\hline
\end{tabular}

Dari Tabel 1 menunjukkan bahwa hasil uji normalitas dengan menggunakan teknik One Sample Kolmogorov-Smirnov pada variabel internal locus of control, spiritualitas, dan kesejahteraan psikologis diperoleh nilai signifikansi $0,200(p>0,05)$. Artinya data variabel pada penelitian telah terdistribusi secara normal.

Tabel 2.

Uji Asumsi Dasar Linieritas Data Penelitian

\begin{tabular}{ccccc}
\hline Variabel & Nilai F & Signifikansi & $p$ & Keterangan \\
\hline $\begin{array}{c}\text { Kesejahteraan Psikologis * } \\
\text { Internal Locus of Control }\end{array}$ & 70,595 & 0,000 & $p<0,05$ & Linier \\
\hline $\begin{array}{c}\text { Kesejahteraan Psikologis * } \\
\text { Spiritualitas }\end{array}$ & 95,764 & 0,000 & $p<0,05$ & Linier \\
\hline
\end{tabular}

Hasil uji linieritas pada variabel internal locus of control dengan kesejahteraan psikologis memperoleh nilai koefisien $\mathrm{F}$ sebesar 70,595 dengan nilai signifikansi 0,000 $(p<0,05)$. Hasil tersebut menunjukkan bahwa adanya hubungan linier antara kedua variabel. Hasil uji linieritas antara variabel spiritualitas dan kesejahteraan psikologis menunjukkan bahwa nilai koefisien F sebesar 95,764 dengan nilai signifikansi 0,000 $(p<0,05)$. Artinya data antara kedua variabel linier.

Tabel 3. 
Uji Asumsi Klasik Multikolinieritas Data Penelitian

\begin{tabular}{cccl}
\hline Variabel & Tolerance & $\begin{array}{c}\text { Variance Inflation } \\
\text { Factor }(\text { VIF) }\end{array}$ & Keterangan \\
\hline Internal Locus of Control & 0,585 & 1,711 & Tidak terjadi multikolinieritas \\
Spiritualitas & 0,585 & 1,711 & Tidak terjadi multikolinieritas \\
\hline
\end{tabular}

Hasil uji multikolinieritas dapat diketahui bahwa nilai Tolerance variabel internal locus of control dan spiritualitas sebesar 0,585 $(>0,01)$ serta nilai VIF sebesar 1,711 $(<10)$ sehingga dapat ditarik kesimpulan bahwa di antara variabel bebas internal locus of control dan spiritualitas tidak terjadi multikolinieritas.

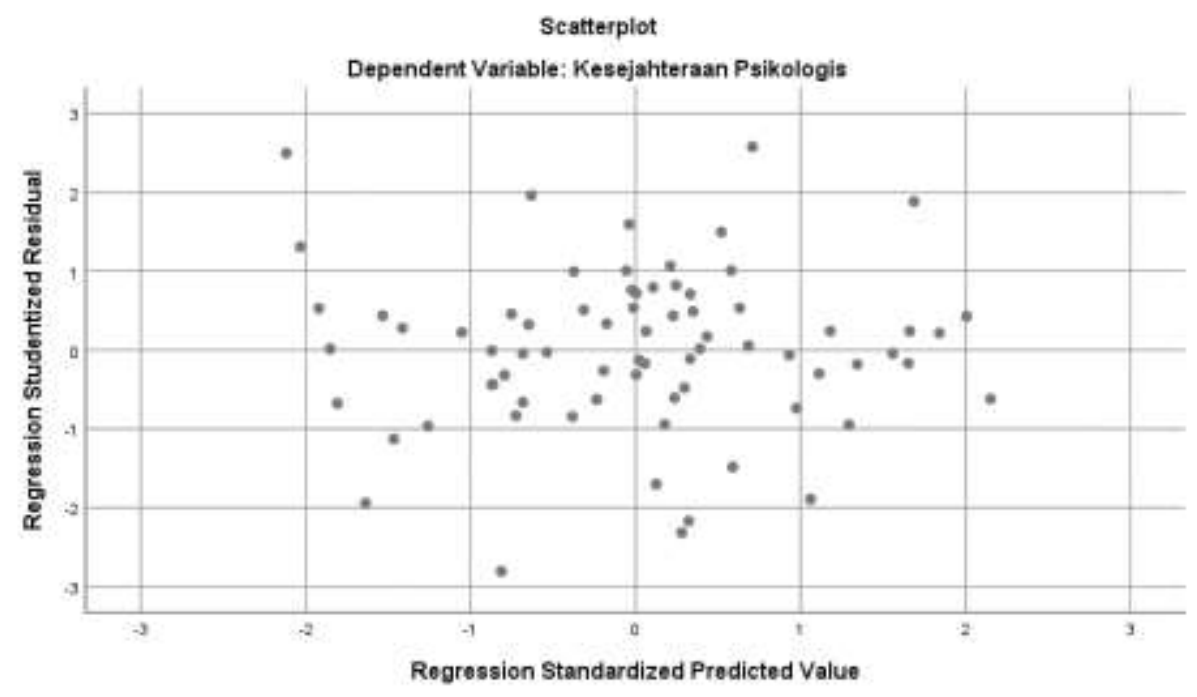

Gambar 1. Hasil uji asumsi klasik heterokedastisitas

Hasil uji heterokedastisitas yang dilakukan dengan melihat titik-titik pada pola scatterplots menunjukkan bahwa titik menyebar secara acak dan merata di bagian atas dan bagian bawah angka 0 pada sumbu $\mathrm{Y}$ sehingga dapat dikatakan bahwa tidak terdapat masalah pada heterokedastisitas dalam model regresi.

Tabel 4.

Uji Asumsi Klasik Autokorelasi Data Penelitian

\begin{tabular}{ccc}
\hline Variabel & Durbin-Watson & Keterangan \\
\hline $\begin{array}{c}\text { Internal Locus of Control dan Spiritualitas } \\
\text { dengan Kesejahteraan Psikologis }\end{array}$ & 2,293 & $\begin{array}{l}\text { Tidak terjadi } \\
\text { autokorelasi }\end{array}$ \\
\hline
\end{tabular}

Hasil uji autokorelasi menunjukkan bahwa nilai dW sebesar 2,293. Sedangkan data tabel dW dengan signifikansi 0,05 dan jumlah data $(N)=75$, serta variabel bebas $(k)=2$. Berdasarkan tabel distribusi Durbin-Watson, diketahui bahwa nilai $\mathrm{dU}=1,5709$ dan nilai $\mathrm{dL}=1,6802$. Nilai dW berada di antara dU dan (4-dU) yakni 1,5709 <2,293 <2,429. sehingga dapat ditarik kesimpulan bahwa tidak ditemukan masalah autokorelasi. 
Tabel 5.

Hasil Uji Hipotesis Regresi Berganda

\begin{tabular}{cccc}
\hline Variabel & $\begin{array}{c}\text { Koefisien } \\
\text { Korelasi }\left(\mathbf{R}_{\mathbf{y} \times 1 \times 2}\right)\end{array}$ & $\begin{array}{c}\text { Koefisien } \\
\text { Determinasi } \mathbf{R}^{2}\end{array}$ & $\begin{array}{c}\text { Standar Estimasi } \\
\text { Kesalahan }\end{array}$ \\
\hline $\begin{array}{c}\text { Kesejahteraan Psikologis * } \\
\text { Internal Locus of Control * } \\
\text { Spiritualitas }\end{array}$ & 0,790 & 0,625 & 4,903 \\
\hline
\end{tabular}

Berdasarkan hasil analisis regresi berganda yang telah dilakukan pada hubungan antara internal locus of control dan spiritualitas dengan kesejahteraan psikologis diperoleh nilai koefisien korelasi $R_{y \times 1 \times 2}$ sebesar 0,790 dengan nilai signifikansi 0,000 ( $\left.p<0,05\right)$ yang menunjukkan arah positif, yaitu semakin tinggi internal locus of control dan spiritualitas maka semakin tinggi pula kesejahteraan psikologis pada remaja yang tinggal di panti asuhan. Begitu pula sebaliknya, apabila semakin rendah internal locus of control dan spiritualitas maka semakin rendah kesejahteraan psikologis remaja yang tinggal di panti asuhan. Nilai koefisien determinasi $\left(R^{2}\right)$ sebesar $=0,625$, memiliki arti bahwa secara bersamasama internal locus of control dan spiritualitas memberikan sumbangan efektif sebesar $62,5 \%$ sedangkan sisanya sebesar 37,5\% ditentukan oleh faktor lain yang tidak diungkap pada penelitian ini. Berdasarkan uraian hasil penelitian di atas dapat membuktikan bahwa hipotesis dapat diterima.

Tabel 6.

Hasil Uji Hipotesis Regresi Sederhana 1

\begin{tabular}{cccc}
\hline Variabel & $\begin{array}{c}\text { Koefisien } \\
\text { Korelasi }\left(\mathbf{r}_{\mathbf{x} 1 \mathbf{y}}\right)\end{array}$ & $\begin{array}{c}\text { Koefisien } \\
\text { Determinasi }\left(\mathbf{R}^{2}\right)\end{array}$ & Signifikansi \\
\hline $\begin{array}{c}\text { Kesejahteraan Psikologis * } \\
\text { Internal Locus of Control }\end{array}$ & 0,466 & 0,30 & 0,000 \\
\hline
\end{tabular}

Berdasarkan hasil uji regresi sederhana pertama yang telah dilakukan pada hubungan antara internal locus of control dengan kesejahteraan psikologis diperoleh nilai koefisien korelasi Rx1y sebesar 0,466 dengan nilai signifikansi 0,000 $(p<0,05)$ yang menunjukkan arah positif. Maka semakin tinggi internal locus of control pada remaja yang tinggal di panti asuhan, maka semakin tinggi pula kesejahteraan psikologis. Begitu pula sebaliknya, apabila internal locus of control pada remaja yang tinggal di panti asuhan semakin rendah, maka semakin rendah pula kesejahteraan psikologis. Besarnya nilai koefisien determinasi $\left(R^{2}\right)$ sebesar $=0,30$ menunjukkan bahwa internal locus of control memiliki sumbangan efektif sebesar 30\% terhadap kesejahteraan psikologis, sedangkan sisanya sebesar $70 \%$ ditentukan adanya faktor lain yang tidak diungkap dalam penelitian ini. Berdasarkan uraian hasil penelitian di atas dapat disimpulkan bahwa hipotesis dapat diterima. 
Tabel 7.

Hasil Uji Hipotesis Regresi Sederhana 2

\begin{tabular}{|c|c|c|c|}
\hline Variabel & $\begin{array}{c}\text { Koefisien } \\
\text { Korelasi }\left(\mathbf{r}_{x 1 y}\right)\end{array}$ & $\begin{array}{c}\text { Koefisien } \\
\text { Determinasi }\left(\mathbf{R}^{2}\right)\end{array}$ & Signifikansi \\
\hline $\begin{array}{l}\text { Kesejahteraan Psikologis * } \\
\text { Spiritualitas }\end{array}$ & 0,490 & 0,325 & 0,000 \\
\hline
\end{tabular}

Berdasarkan hasil uji regresi sederhana kedua yang telah dilakukan pada hubungan antara spiritualitas dengan kesejahteraan psikologis diperoleh nilai koefisien korelasi $R_{x 2 y}$ sebesar 0,490 dengan nilai signifikansi $0,000(p<0,05)$ yang menunjukkan arah positif. Maka semakin tinggi spiritualitas pada remaja yang tinggal di panti asuhan, maka semakin tinggi pula kesejahteraan psikologis. Begitu pula sebaliknya, apabila spiritualitas pada remaja yang tinggal di panti asuhan semakin rendah, maka semakin rendah pula kesejahteraan psikologis. Besarnya nilai koefisien determinasi $\left(R^{2}\right)$ sebesar $=0,325$ menunjukkan bahwa spiritualitas memiliki sumbangan efektif sebesar 32,5\% terhadap kesejahteraan psikologis, sedangkan sisanya sebesar $67,5 \%$ ditentukan adanya faktor lain yang tidak diungkap dalam penelitian ini. Berdasarkan uraian hasil penelitian di atas dapat disimpulkan bahwa hipotesis dapat diterima.

Tabel 8.

Hasil Analisis Deskriptif Data Penelitian

\begin{tabular}{ccccc}
\hline Variabel & Kategorisasi & Norma & \multicolumn{2}{c}{ Jumlah Responden } \\
\cline { 3 - 5 } & & & $\mathbf{F}$ & $\mathbf{\%}$ \\
\hline Kesejahteraan & Rendah & $\mathrm{X}<56$ & 0 & 0 \\
Psikologis & Sedang & $56 \leq \mathrm{X}<84$ & 31 & 41,33 \\
& Tinggi & $\mathrm{X} \geq 84$ & 44 & $\mathbf{5 8 , 6 7}$ \\
\hline Internal Locus of & Rendah & $\mathrm{X}<44$ & 0 & 0 \\
Control & Sedang & $44 \leq \mathrm{X}<66$ & 55 & $\mathbf{7 3 , 3 3}$ \\
& Tinggi & $\mathrm{X} \geq 66$ & 20 & 26,67 \\
\hline \multirow{2}{*}{ Spiritualitas } & Rendah & $X<52$ & 0 & 0 \\
& Sedang & $52 \leq X<78$ & 14 & 18,67 \\
& Tinggi & $X \geq 78$ & 61 & $\mathbf{8 1 , 3 3}$ \\
\hline
\end{tabular}

Berdasarkan Tabel 8, diperoleh penjelasan bahwa hasil analisis deskriptif variabel kesejahteraan psikologis menunjukkan sebanyak 31 responden atau 41,33\% memiliki tingkat kesejahteraan psikologis dengan kategori sedang, dan sebanyak 44 responden atau 58,67\% memiliki tingkat kesejahteraan psikologis dengan kategori tinggi. Berdasarkan data di atas dapat disimpulkan bahwa sebagian besar remaja yang tinggal di panti asuhan memiliki tingkat kesejahteraan psikologis dengan kategori tinggi. 
Hasil analisis deskriptif variabel internal locus of control menunjukkan sebanyak 55 responden atau 73,33\% memiliki tingkat internal locus of control dengan kategori sedang, dan sebanyak 20 responden atau 26,67\% memiliki tingkat internal locus of control dengan kategori tinggi. Berdasarkan data di atas dapat disimpulkan bahwa sebagian besar remaja yang tinggal di panti asuhan memiliki tingkat internal locus of control dengan kategori sedang.

Hasil analisis deskriptif variabel spiritualitas menunjukkan sebanyak 14 responden atau $18,67 \%$ memiliki tingkat spiritualitas dengan kategori sedang, dan sebanyak 61 responden atau $81,33 \%$ memiliki tingkat spiritualitas dengan kategori tinggi. Berdasarkan data di atas dapat disimpulkan bahwa sebagian besar remaja yang tinggal di panti asuhan memiliki tingkat spiritualitas dengan kategori tinggi.

Tabel 9.

Hasil Uji Analisis Tambahan Kruskal Wallis Berdasarkan Jenis Kelamin

\begin{tabular}{cccccc} 
& Asymp. Sig. & Jenis Kelamin & Jumlah & Rerata & Kategorisasi \\
\cline { 2 - 6 } Kesejahteraan & \multirow{4}{*}{0,640} & Laki-laki & 40 & 36,90 & Tinggi \\
Psikologis & Perempuan & 35 & 39,26 & Tinggi \\
& & Total & 75 & & \\
\hline
\end{tabular}

Analisis tambahan ini dilakukan dengan menggunakan Uji Kruskal Wallis melalui SPSS untuk melihat apakah terdapat perbedaan kesejahteraan psikologis antara laki-laki dengan perempuan. Pada tabel hasil uji Kruskal Wallis di atas diketahui bahwa nilai signifikansi adalah 0,640 ( $p>0,05)$. Oleh karena itu dapat disimpulkan bahwa tidak terdapat perbedaan yang signifikan pada variabel kesejahteraan psikologis ditinjau dari jenis kelamin pada remaja yang tinggal di Panti Asuhan.

Tabel 10.

Hasil Uji Analisis Tambahan Kruskal Wallis Berdasarkan Usia

\begin{tabular}{cccccc}
\hline & Asymp. Sig. & Usia & Jumlah & Rerata & Kategorisasi \\
\cline { 2 - 6 } Kesejahteraan & & 12-15 tahun & 32 & 36,95 & Tinggi \\
Psikologis & 0,699 & 16-19 tahun & 34 & 37,47 & Tinggi \\
& & 20-23 tahun & 9 & 43,72 & Tinggi \\
& & Total & 75 & \\
\hline
\end{tabular}

Ryff dan Singer (2006) mengemukakan bahwa perbedaan usia memengaruhi perbedaan dalam kesejahteraan psikologis bahwa peningkatan sering bertambah usia juga menunjukkan kedewasaan. Pada Tabel 10 diketahui bahwa nilai signifikansi adalah 0,699 ( $p$ $>0,05)$. Oleh karena itu dapat disimpulkan bahwa tidak terdapat perbedaan yang signifikan pada variabel kesejahteraan psikologis ditinjau dari usia pada remaja yang tinggal di panti asuhan. 
Ryff dan Heidrich (1997) menyatakan bahwa pendidikan menjadi salah satu prediktor kesejahteraan psikologis pada individu. Pada Tabel 11 diketahui bahwa nilai signifikansi adalah 0,040 $(p<0,05)$. Oleh karena itu dapat disimpulkan bahwa terdapat perbedaan yang signifikan pada variabel kesejahteraan psikologis ditinjau dari pendidikan pada remaja yang tinggal di panti asuhan.

Tabel 11.

Hasil Uji Analisis Tambahan Kruskal Wallis Berdasarkan Jenjang Pendidikan

\begin{tabular}{cccccc}
\hline & $\begin{array}{c}\text { Asymp. } \\
\text { Sig. }\end{array}$ & $\begin{array}{c}\text { Jenjang } \\
\text { Pendidikan }\end{array}$ & Jumlah & Rerata & Kategorisasi \\
\cline { 2 - 6 } & & SD & 5 & 9,80 & Sedang \\
Kesejahteraan & & SMP & 23 & 38,13 & Tinggi \\
Psikologis & 0,040 & SMA & 8 & 46,88 & Tinggi \\
& & SMK & 33 & 40,03 & Tinggi \\
& & Perguruan Tinggi & 6 & 38,00 & Tinggi \\
& & Total & 75 & & \\
\hline
\end{tabular}

Tabel 12.

Hasil Uji Analisis Tambahan Kruskal Wallis Berdasarkan Lama Tinggal di Panti Asuhan

\begin{tabular}{cccccc} 
& Asymp. Sig. & Lama Tinggal & Jumlah & Rerata & Kategorisasi \\
\cline { 2 - 6 } & & $1-5$ tahun & 36 & 33,72 & Sedang \\
Kesejahteraan & & 6-10 tahun & 24 & 37,25 & Tinggi \\
Psikologis & \multirow{2}{*}{0,028} & $11-15$ tahun & 11 & 41,68 & Tinggi \\
& & 16-20 tahun & 2 & 72,50 & Tinggi \\
& & $>20$ tahun & 2 & 69,25 & Tinggi \\
& & Total & 75 & \\
\hline
\end{tabular}

Dina (2010) pada penelitiannya mengemukakan bahwa mereka yang sudah tinggal di panti asuhan minimal paling tidak satu tahun sudah memahami bagaimana karakter lingkungan tempat tinggalnya, sehingga memiliki penyesuaian yang lebih baik untuk melibatkan diri dengan lingkungan sosialnya. Pada Tabel 12 diketahui bahwa nilai signifikansi adalah 0,028 $(p<0,05)$. Oleh karena itu dapat disimpulkan bahwa terdapat perbedaan yang signifikan pada variabel kesejahteraan psikologis ditinjau dari lama tinggal di panti asuhan pada remaja yang tinggal di panti asuhan.

Tabel 13.

Hasil Uji Analisis Tambahan Kruskal Wallis Berdasarkan Keberadaan Orang Tua

\begin{tabular}{cccccc} 
& Asymp. Sig. & Usia & Jumlah & Rerata & Kategorisasi \\
\cline { 2 - 6 } & & Lengkap & 55 & 36,22 & Tinggi \\
Kesejahteraan & & Yatim & 8 & 32,56 & Sedang \\
Psikologis & \multirow{2}{*}{0,213} & Piatu & 3 & 46,33 & Tinggi \\
& & Yatim Piatu & 9 & 50,94 & Tinggi \\
& & Total & 75 & & \\
\hline
\end{tabular}


Yendork dan Somhlaba (2014) menjelaskan bahwa tidak adanya figur orang tua yang mendampingi kehidupan remaja dapat menjadi stressor yang berisiko menurunkan kesejahteraan psikologis. Pada Tabel 13 diketahui bahwa nilai signifikansi adalah 0,213 ( $p$ > $0,05)$. Oleh karena itu dapat disimpulkan bahwa tidak terdapat perbedaan yang signifikan pada variabel kesejahteraan psikologis ditinjau dari keberadaan orang tua pada remaja yang tinggal di panti asuhan.

\section{Diskusi}

Hasil uji hipotesis pada penelitian ini sejalan dengan penelitian Ryff dan Singer (2006) yang menyatakan bahwa faktor psikososial yang di dalamnya termasuknya spiritualitas mampu berpengaruh terhadap kesejahteraan psikologis. Individu dengan spiritualitas yang tinggi membuat individu mempunyai strategi koping yang baik sehingga dapat berpengaruh terhadap kesejahteraan psikologis (Cornah, 2006). Selain itu, ketika individu memiliki spiritualitas yang tinggi, maka harga diri dan makna hidup yang dimiliki semakin tinggi, yang mana hal tersebut menjadi indikasi tercapainya kesejahteraan psikologis (Kashdan \& Nezlek, 2012). Berdasarkan hasil penelitian ini, peneliti mengambil kesimpulan bahwa spiritualitas menjadi faktor yang memengaruhi kesejahteraan psikologis individu. Faktor lain yang berpengaruh terhadap kesejahteraan psikologis pada remaja yang tinggal di panti asuhan adalah internal locus of control. Hal ini didukung oleh penelitian terdahulu yaitu hasil penelitian Arifin dan Rahayu (2012) yang mengatakan bahwa mereka dengan internal locus of control cenderung lebih tabah dalam menghadapi stressor yang ada. Individu dengan internal locus of control juga mampu menentukan nasibnya sendiri terlepas dari lingkungannya mendukung atau tidak sehingga menjadi prediktor penting untuk mengetahui kesejahteraan psikologis.

Hasil uji regresi sederhana pertama sesuai dengan penelitian Mobarakeh et al. (2015) yang menyatakan bahwa internal locus of control memainkan peran dasar untuk menentukan tingkat penyesuaian dan kesejahteraan psikologis. Remaja dengan internal locus of control mampu mengadopsi penguasaan diri dan cenderung memiliki hubungan sosial yang bermanfaat dan berdampak positif pada kinerja kelompoknya sehingga terjadi peningkatan pada kesejahteraan psikologisnya. Penelitian ini juga sejalan dengan penelitian Listiara dan Sari (2017) menunjukkan bahwa internal locus of control memiliki korelasi positif dengan kesejahteraan psikologis. Individu dengan internal locus of control mempunyai kepercayaan yang kuat bahwa kesuksesan dan kegagalan di hidupnya ditentukan oleh usahanya sendiri. Mereka dengan internal locus of control yang tinggi mengalami peningkatan pada job performance sehingga memicu terbentuknya relasi positif dan pengembangan diri. Sesuai dengan teori Ryff (2014) bahwasanya relasi positif dan pengembangan diri merupakan dimensi dari kesejahteraan psikologis. 
Hasil uji regresi sederhana kedua mendukung penelitian terdahulu dari Kashdan dan Nezlek (2012), dikatakan bahwa spiritualitas memiliki korelasi positif dengan kesejahteraan psikologis. Individu dengan spiritualitas yang tinggi akan memiliki harga diri dan afek positif yang tinggi, yang mana hubungan tersebut dimediasi oleh makna kehidupan. Spiritualitas dapat memengaruhi kehidupan individu dengan mengubah nilai-nilai dan sikap mereka, kepercayaan tentang diri dan dunia, dan kesadaran serta pemahaman peristiwa dengan potensi pembuatan makna. Lebih jauh, orang yang spiritual dapat memanfaatkan perasaan spiritual daripada orang yang kurang spiritual. Selain itu, penelitian ini juga sejalan dengan penelitian oleh Rahmah dan Lisnawati (2018), diungkapkan bahwa spiritualitas dan kesejahteraan psikologis mempunyai hubungan yang positif. Kondisi spiritual yang baik merupakan petunjuk individu dalam memahami eksistensi manusia dalam mengarahkan dan memaknai kehidupannya, sehingga spiritualitas menjadi salah satu upaya individu dalam mencapai kondisi kesejahteraan psikologis yang baik.

Berdasarkan hasil kategorisasi data deskriptif mengenai kesejahteraan psikologis pada remaja yang tinggal di panti asuhan menunjukkan bahwa 58,67\% responden memiliki tingkat kesejahteraan psikologis yang tinggi. Jadi dapat dikatakan bahwa sebagian besar remaja yang tinggal di panti asuhan memiliki tingkat kesejahteraan psikologis yang tinggi. Hasil penelitian ini sesuai dengan penelitian Sari (2015) yang membuktikan bahwa 70\% remaja panti memiliki tingkat kesejahteraan psikologis yang tinggi. Selanjutnya, kategorisasi variabel internal locus of control menunjukkan sebanyak $0 \%$ responden dalam penelitian ini memiliki tingkat internal locus of control yang rendah, 73,33\% responden memiliki tingkat internal locus of control yang sedang, dan $26,67 \%$ responden memiliki tingkat internal locus of control yang tinggi. Jadi dapat dikatakan bahwa sebagian besar remaja yang tinggal di panti asuhan memiliki memiliki kemampuan yang sedang dalam mengambil keputusan, berperilaku mandiri, serta meyakini bahwa kesuksesannya bersumber dari usahanya sendiri. Kemudian, kategorisasi variabel spiritualitas menunjukkan 81,33\% responden memiliki tingkat spiritualitas yang tinggi. Jadi dapat dikatakan bahwa sebagian besar remaja yang tinggal di panti asuhan memiliki rasa keterhubungan kuat pada yang Kuasa sebagai hal mendasar yang mengacu pada penciptaan makna dalam dirinya.

Analisis tambahan yang dilakukan guna melengkapi data penelitian ini adalah analisis mengenai perbedaan skor kesejahteraan psikologis ditinjau dari jenis kelamin, usia, pendidikan, lama tinggal di panti asuhan, dan keberadaan dari orang tua. Berdasarkan hasil kelima analisis tersebut, ditemukan perbedaan yang signifikan pada dua tinjauan, yaitu pendidikan dan lama tinggal di panti asuhan. Hasil tersebut menunjang penelitian Ryff (2014) bahwa tingkat pendidikan mampu memberikan pengaruh terhadap tingkat kesejahteraan psikologis. Hasil kesejahteraan psikologis ditinjau dari lama tinggal di panti asuhan sesuai dengan data yang terkumpul, didapatkan bahwa semakin lama responden tinggal di panti asuhan, maka semakin tinggi pula kesejahteraan psikologisnya hingga batas durasi selama 20 tahun. Temuan ini merupakan penemuan terbaru yang belum pernah dikaji sebelumnya. 
Ditinjau dari jenis kelamin, hasil penelitian ini sesuai dengan penelitian Saputri (2013) mengenai kesejahteraan psikologis yang menunjukkan bahwa tidak terdapat perbedaan yang signifikan ditinjau dari jenis kelamin pada remaja. Berbeda dengan penelitian Ryff dan Singer (2006) yang melakukan penelitian terhadap dewasa akhir. Hasil analisis mengungkapkan bahwa terdapat perbedaan yang signifikan pada skor kesejahteraan psikologis berdasarkan pendidikan. Kemudian jika ditinjau dari usia, tidak ditemukan adanya perbedaan yang signifikan pada kesejahteraan psikologis karena usia subjek yang masih remaja, berbeda dengan penelitian sebelumnya yang dilakukan pada dewasa tengah. Selain itu, penelitian sebelumnya oleh Karasawa, et al. (2011) mengenai usia dan kesejahteraan psikologis juga bervariasi tergantung konteks budaya. Berbeda dengan penelitian ini, dimana subjeknya berasal dari konteks budaya yang sama.

\section{Kesimpulan}

Berdasarkan penelitian yang telah dilakukan, maka dapat disimpulkan bahwa terdapat hubungan antara internal locus of control dan spiritualitas dengan kesejahteraan psikologis pada remaja yang tinggal di panti asuhan Kabupaten Karanganyar, Jawa Tengah. Semakin tinggi internal locus of control dan spiritualitas, maka semakin tinggi kesejahteraan psikologis. Sebaliknya, semakin rendah internal locus of control dan spiritualitas maka semakin rendah kesejahteraan psikologis. Berdasarkan hasil uji hipotesis lainnya juga diketahui bahwa ada hubungan positif antara internal locus of control dengan kesejahteraan psikologis. Makin tinggi internal locus of control, maka makin tinggi kesejahteraan psikologis dan sebaliknya. Selanjutnya, terdapat hubungan antara spiritualitas dengan kesejahteraan psikologis. Makin tinggi spiritualitas, maka makin tinggi kesejahteraan psikologis dan sebaliknya. Berdasarkan hasil penelitian juga diketahui bahwa spiritualitas memiliki kontribusi lebih besar terhadap kesejahteraan psikologis dengan memberikan sumbangan efektif sebesar 32,5\%, sedangkan internal locus of control memberikan sumbangan efektif sebesar $30 \%$.

\section{Saran}

Hasil penelitian ini diharapkan dapat menjadi salah satu pertimbangan bagi pihak pengelola panti asuhan untuk memperhatikan kesejahteraan psikologis anak asuhnya. Selain itu, program pelatihan pengembangan diri seperti motivation training atau leadership training dapat dilaksanakan sebagai upaya meningkatkan internal locus of control. Pihak pengelola panti diharapkan mengadakan pelatihan mengenai spiritualitas seperti kesadaran diri, kesadaran relasional, meditasi atau mindfullness. Peneliti selanjutnya diharapkan mampu mengkaji lebih dalam tentang kesejahteraan psikologis pada remaja di panti asuhan sampai ke tiap-tiap dimensinya. Selain itu, mampu membahas lebih lanjut mengenai analisis tambahan yang dibuktikan oleh penelitian ini, seperti bagaimana hubungan antara 
pendidikan dengan kesejahteraan psikologis, serta antara lama tinggal di panti asuhan dengan kesejahteraan psikologis remaja di panti asuhan.

\section{Kepustakaan}

Aesijah, S., Prihartanti, N., \& Pratisti, W. D. (2016). Pengaruh pelatihan regulasi emosi terhadap kebahagiaan remaja panti asuhan yatim piatu. Jurnal Indigenous, 1(1), 39-47. https://doi.org/10.23917/indigenous.v1i1.1792

Arifin, Z., \& Rahayu, I. T. (2012). Hubungan antara orientasi religius, locus of control dan psychological well-being mahasiswa Fakultas Psikologi Universitas Islam Negeri Maulana Malik Ibrahim Malang. Jurnal Psikologi Universitas Islam Negeri Maulana Malik Ibrahim Malang.

Cornah, D. (2006). The impact of spirituality on mental health: A review of the literature. Mental Health Foundation.

Dina, Y. (2010). Hubungan antara peneriman diri dengan kompetensi interpersonal pada remaja panti asuhan. Skripsi, Universitas Muhammadiyah Surakarta.

Elkins, D., Hedstrom, L. J., Hughes, L. L., Leaf, J. A., \& Saunders, C. (1988). Toward a humanistic phenomenological spirituality. Journal of Humanistic Psychology, 28(4), 518. https://doi.org/10.1177/0022167888284002

Haileigiorgis, M. T., Berheto, T. M., Sibamo, E. L., Assefa, N. A., Tesfa, G., \& Birhanu, F. (2018). Psychological wellbeing of children at public primary schools in Jimma Town: An orphan and non-orphan comparative study. PloS one, 13(4). https://doi.org/10.1371/journal.pone.0195377

Huppert, F. A. (2009). Psychological well-being: Evidence regarding its causes and consequences. Applied Psychology: Health and Well-Being, 1(2), 137-164. https://doi.org/10.1111/j.1758-0854.2009.01008.x

Illahi, S. P., \& Akmal, S. Z. (2018). Hubungan kelekatan dengan teman sebaya dan kecerdasan emosi pada remaja yang tinggal di panti asuhan. Psikohumaniora: Jurnal Penelitian Psikologi, 2(2), 171-181. https://doi.org/10.21580/pjpp.v2i2.1854

Karasawa, M., Curhan, K. B., Markus, H., Kitayama, S., Love, G. D., Radler, B. T., \& Ryff, C. D. (2011). Cultural perspectives on aging and well-being: A Comparison and The United States. International Journal of Aging and Human Development, 73(1), 73-98. https://doi.org/10.2190/AG.73.1.d

Kashdan, T. B., \& Nezlek, J. B. (2012). Whether, when, and how is spirituality related to wellbeing? Moving beyond single occasion questionnaires to understanding daily process. Personality and Social Psychology Bulletin, 38(11), 1523-1535. https://doi.org/10.1177/0146167212454549

KPAI, T. (2020, Februari 10). Sejumlah kasus bullying sudah warnai catatan masalah anak di awal 2020, Begini kata komisioner KPAI. Retrieved April 19, 2020, from Komisi 
Perlindungan Anak Indonesia: kpai.go.id/berita/sejumlah-kasus-bullying-sudahwarnai-catatan-masalah-anak-di-awal-2020-begini-kata-komisioner-kpai

Levenson, H. (1973). Multidimensional locus of control in psychiatric patients. Journal of Consulting and Clinical Psychological, 41(3), 397-404.

Listiara, A., \& Sari, C. P. (2017). Hubungan antara lokus pengendalian internal dengan kesejahteraan psikologis pada guru di SMA Negeri di Kota Bogor. Jurnal Empati, 6(1), 65-69.

Malik, N., \& Tanzeel, S. (2017). Spirituality and psychological well-being among muslims and christians adolescents and young adults. Al-Idah, Shaykh Zayed Islamic Centre, University Peshawar, 35(2), 53-61.

Mobarakeh, M. R., Juhari, R., Yaacob, S. N., \& Redzuan, M. (2015). Locus of control and psychological well-being among Iranian adolescents migrants in Kuala Lumpur, Malaysia. American International Journal of Research in Humanities, Arts, and SocialSciences, 10(3), 310-313.

Munthe, B. E., Maslihah, S., \& Chotidjah, S. (2017). Hubungan spiritualitas dan psyhological well-being pada anak didik pemasyarakatan di lembaga pemasyarakatan anak pria kelas IIA Tangerang. Jurnal Psikologi Klinis Indonesia, 1(1), 53-65.

Okti, R. (2019). Psychological well-being pada remaja di Panti Asuhan Bintang Terampil Bengkulu. Skripsi, Institut Agama Islam Negeri Bengkulu.

Pandya, S. P. (2017). Spirituality, happiness, and psychological well-being in 13-15 year olds: A Cross-Country longitudinal RCT study. Joirnal of Pastoral Care \& Counseling, 71(1), 12-26. https://doi.org/10.1177/1542305016687581

Prabowo, A. (2016). Kesejahteraan psikologis remaja di sekolah. Jurnal Ilmiah Psikologi Terapan, 4(2), 246-260. https://doi.org/10.22219/jipt.v4i2.3527

Rahmah, I. A., \& Lisnawati. (2018). Kesejahteraan psikologis ditinjau dari spiritualitas siswa di lembaga pendidikan berbasis agama pesantren dan non-pesantren. Jurnal Psikologi Integratif, 6(2), 190-212. https://doi.org/10.14421/jpsi.v6i2.1499

Rotter, J. B. (1966). Generalized expectancies for internal versus external control of reinforcement. Psychological Monographs: General and Applied, 80(1), 1-28.

Ryff. C. D. (2014). Psychological well-being revisited: Advances in the science and practice of $\begin{array}{llll}\text { eudaimonia. Psychoterapy and } & \text { 10-28. }\end{array}$ https://doi.org/10.1159/000353263

Ryff, C. D., \& Heidrich, S. M. (1997). Experience and well-being: Explorations on domains of life and how they matter. International Journal of Behavioral Development, 20(2), 193206. https://doi.org/10.1080/016502597385289

Ryff, C. D., \& Singer, B. H. (2006). Know thyself and become what you are: A eudaimonic approach to psychological well-being. Journal of Happiness Studies: An Interdiciplinary Forum on Subjective Well-Being, 9(1), 13-39. https://doi.org/10.1007/s10902-006-9019-0

Saputri, S. A. (2013). Hubungan antara religiusitas dan dukungan sosial dengan psychologival well-being pada santri Kelas VIII Pondok Pesantren Tahfidzul Qur-an Ibnu Abbas Klaten. Skripsi, Universitas Sebelas Maret Surakarta. 
Sari, R. R. (2015). Tingkat psychological well-being pada remaja di Panti Sosial Bina Remaja Yogyakarta. E-journal Bimbingan dan Konseling, 12(4), 1-9.

Solari, C. D., \& Mare, R. D. (2012). Housing crowding effects on childrens wellbeing. Social Science Research, 41(2), 464-476. https://doi.org/10.1016/j.ssresearch.2011.09.012

Underwood, L. G., \& Teresi, J. (2002). The daily spiritual experience scale: development, theoretical, description, reliability, exploratory factor analysis, and preliminary construct validity using health related data. Annals of Behavioral Medicine, 24(1), 22-33. https://doi.org/10.1207/S15324796ABM2401 04.

Yendork, J. S., \& Somhlaba, N. Z. (2014). Stress, coping and quality of life: An exploratory study of the psychological well-being of ghanaian orphans placed in orphanages. Children and Youth Services Review, 1(46), 28-37. https://doi.org/10.1016/j.childyouth.2014.07.025 